\title{
Stratified Entomological Sampling in Preparation for an Area-Wide Integrated Pest Management Program: The Example of Glossina palpalis gambiensis (Diptera: Glossinidae) in the Niayes of Senegal
}

\author{
JÉRÉMY BOUYER, ${ }^{1,2,3}$ MOMAR TALLA SECK, ${ }^{2}$ BABA SALL,${ }^{4}$ ELHADJI YOUSSOU NDIAYE, ${ }^{4}$ \\ LAURE GUERRINI, ${ }^{1,5}$ AND MARC J. B. VREYSEN ${ }^{6}$
}

J. Med. Entomol. 47(4): 543-552 (2010); DOI: 10.1603/ME09149

\begin{abstract}
The riverine tsetse species Glossina palpalis gambiensis Vanderplank 1949 (Diptera: Glossinidae) inhabits riparian forests along river systems in West Africa. The government of Senegal has embarked on a project to eliminate this tsetse species, and African animal trypanosomoses, from the Niayes area using an area-wide integrated pest management approach. A stratified entomological sampling strategy was therefore developed using spatial analytical tools and mathematical modeling. A preliminary phytosociological census identified eight types of suitable habitat, which could be discriminated from LandSat $7 \mathrm{ETM}^{+}$satellite images and denominated wet areas. At the end of March 2009, 683 unbaited Vavoua traps had been deployed, and the observed infested area in the Niayes was $525 \mathrm{~km}^{2}$. In the remaining area, a mathematical model was used to assess the risk that flies were present despite a sequence of zero catches. The analysis showed that this risk was above $0.05 \mathrm{in} 19 \%$ of this area that will be considered as infested during the control operations. The remote sensing analysis that identified the wet areas allowed a restriction of the area to be surveyed to $4 \%$ of the total surface area $\left(7,150 \mathrm{~km}^{2}\right)$, whereas the mathematical model provided an efficient method to improve the accuracy and the robustness of the sampling protocol. The final size of the control area will be decided based on the entomological collection data. This entomological sampling procedure might be used for other vector or pest control scenarios.
\end{abstract}

KEY WORDS stratified sampling, vector control, tsetse, remote sensing, African animal trypanosomosis

In the subhumid savannah of West Africa, riverine tsetse species such as Glossina palpalis gambiensis Vanderplank 1949 inhabit riparian forests along river systems, where they are major vectors of African an-

\footnotetext{
${ }^{1}$ Centre de Coopération Internationale en Recherche Agronomique pour le Développement, Unité Mixte de Recherche Centre de Coopération Internationale en Recherche Agronomique pour le Développement-Institut National de la Recherche Agronomique Contrôle des Maladies Animales, Campus International de Baillarguet, F34398, Montpellier, France.

${ }^{2}$ Institut Sénégalais de Recherches Agricoles-Laboratoire National d'Elevage et de Recherches Vétérinaires, Service de Parasitologie, BP 2057, Dakar-Hann, Sénégal.

${ }^{3}$ Corresponding author: Centre de Coopération Internationale en Recherche Agronomique pour le Développement-Département Systèmes Biologiques Unité Mixte de Recherche Contrôle des maladies animales exotiques et émergentes, Institut Sénégalais de Recherches Agricoles-Laboratoire National d'Elevage et de Recherches Vétérinaires, Service de Parasitologie, BP 2057 Dakar-Hann Sénégal (e-mail: bouyer@cirad.fr).

${ }^{4}$ Direction des Services Vétérinaires, 37, avenue Pasteur, BP 67 Dakar, Sénégal.

${ }^{5}$ Centre de Coopération Internationale en Recherche Agronomique pour le Développement, Unité Propre de Recherche Animal et gestion intégrée des risques, Campus International de Baillarguet, F34398, Montpellier, France.

${ }^{6}$ Entomology Unit, Food and Agriculture Organization/International Atomic Energy Agency Agriculture and Biotechnology Laboratory, Joint Food and Agriculture Organization/International Atomic Energy Agency Programme, Vienna, Austria.
}

imal trypanosomosis (AAT) (Bouyer et al. 2006, Guerrini and Bouyer 2007) and human African trypanosomosis or sleeping sickness (Camara et al. 2005). In Senegal, as in other parts of West Africa, AAT is a major obstacle to the development of more efficient and sustainable livestock production systems (Itard et al. 2003), and the presence of tsetse is considered a major root cause of hunger and poverty (Feldmann et al. 2005)

G. p. gambiensis thrives normally in areas that receive a minimum of $600 \mathrm{~mm}$ of rain annually (Brunhes et al. 1998), but in western Senegal the flies survive under very dry conditions, where annual precipitation is limited to $400-500 \mathrm{~mm}$. In addition, the flies seem to have adapted to peri-urban, densely populated areas like the Parc de Hann located in the city center of Dakar and neighboring locations (Sébikotane, Pout). The G. p. gambiensis populations in western Senegal seem to be well adapted to specific habitats called the Niayes that owe their name to vestiges of Guinean forest in low-lying interdune depressions that are periodically or permanently flooded. Well described in their original state by Touré and Morel $>30$ yr ago (Morel and Touré 1967, Touré 1971, 1974), the Niayes are situated northeast from Dakar, but have suffered from an increase in human encroachment, which 


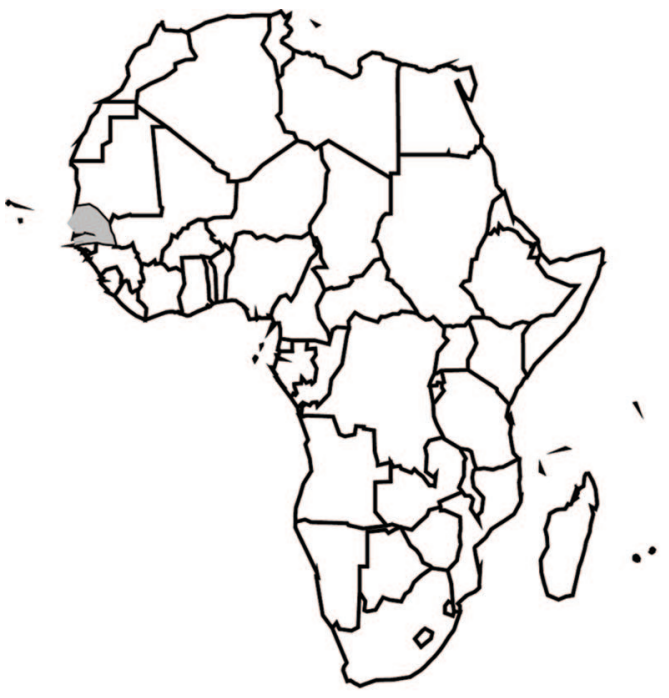

\section{Senegal}

\section{Petite côte}

\section{Legend}

Field censi

$\mathrm{O}$ Learning site

$\diamond \quad$ Validation site

Habitat suitabilty for G. palpalis gambiensis

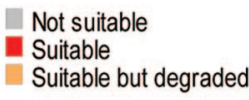

Wet areas

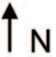

\section{Sine Saloum}

Thiès

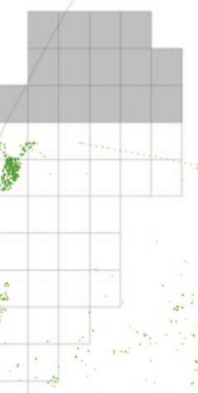

Fig. 1. Location of the study area. The suitability of the vegetation for harboring G. p. gambiensis after a phytosociological census, and the wet areas as obtained from a supervised classification are presented. Gray cells at the top and the bottom of the maps represent areas where no satellite imagery was available.

has dramatically altered this entire ecosystem. La Petite Côte is a similar, albeit drier ecosystem situated south of Dakar, which expands along the Atlantic coast toward Joal and the Sine Saloum river. The tsetse inhabiting the Niayes and La Petite Côte belong to the most northwestern distribution of the tsetse belt in West Africa (Fig. 1). No updated information is currently available on the present status and ecology of the tsetse populations in this special habitat. 
The Niayes area has particular climatic conditions that allow intensive cropping and cattle breeding even during the dry season. In addition to the local breeds, important exotic cattle populations are maintained for the milk production, but their cost effectiveness is continuously threatened by exposure to the trypanosomoses. Horses that are mainly used for the transport of food crops are also present in high densities, and the area contains numerous stud farms with horses of high economic value. Tsetse bites are also a continuous nuisance for human populations, especially in Sebikotane and Pout.

The seriousness of the tsetse and trypanosomosis problems in the Niayes and La Petite Côte was recently revealed during a parasitological and serological survey of resident cattle, where AAT herd prevalence rates of $10-90 \%$ were observed (Seck et al. 2010). The survey showed that Trypanosoma vivax is the most abundant species, followed by Trypanosoma congolense. The parasitological prevalence may be grossly underestimated in reality, because of the poor sensitivity of the diagnostic Buffy coat technique that was used (Pinchbeck et al. 2008).

During consecutive $2 \mathrm{yr}$ in the 1970s, an attempt was made to eliminate the G. $p$. gambiensis populations from $>150 \mathrm{~km}$ of linear habitat in the Niayes area using selective bush clearing and residual ground spraying with a $2 \%$ formulation of dieldrin. After the campaign, no tsetse were detected during two consecutive surveys (Touré 1973). However, tsetse reappeared in the 1980 s, necessitating a second campaign combining insecticide spraying with the deployment of traps and insecticide-impregnated screens. The tsetse problem seemed to have disappeared until flies were detected again in 1998 (B. Sall, unpublished data). These observations prompted the Direction de l'Elevage (DIREL) and the Institut Sénégalais de Recherche Agricole (ISRA) to carry out more extensive surveys in 2003-04, which confirmed the presence of G. $p$. gambiensis in the Niayes (B. Sall, unpublished data). At the time of these surveys, it was not clear whether the resurgence of the fly population could be attributed to reinvasion from the main tsetse belt in the Sine Saloum region, located $>100 \mathrm{~km}$ south of Dakar, or from small residual pockets inside the control area.

In 2005, the DIREL initiated a tsetse control campaign called Projet de lutte contre les glossines dans les Niayes (tsetse control program in the Niayes), which was funded by Senegal and technically and financially supported by the International Atomic Energy Agency (IAEA). The project is being implemented in the context of the Pan African Tsetse and Trypanosomiasis Eradication Campaign (PATTEC), a political initiative of the African heads of state that calls for increased efforts to manage the tsetse and trypanosomosis problem, which is considered a serious impediment to sustainable agricultural rural development in most sub-Saharan African countries (http:// www.africa-union.org/Structure_of_the_ Commission/depPattec.htm).

The tsetse project in Senegal has adopted an areawide integrated pest management (AW-IPM) ap- proach that aims at integrating various control tactics (e.g., traps, insecticide-impregnated targets, live baits, the sterile insect technique) (Dyck et al. 2005) to target an entire tsetse population within a circumscribed area (Klassen 2005). To develop an appropriate AW-IPM strategy, detailed and accurate data are required of the target population. The DIREL and ISRA, in collaboration with the Centre de Coopération Internationale en Recherche Agronomique pour le Développement, the Food and Agriculture Organization, and the IAEA therefore developed a specific entomological sampling protocol to define as precisely as possible the present distribution of tsetse in the Niayes and La Petite Côte. These entomological surveys are part of an entire package of baseline data that include parasitological and serological disease prevalence, tsetse population genetics, and socioeconomic and environmental impact data that will be published elsewhere. A comprehensive analysis of these data will assist the decision-making process of selecting a strategy of sustainable elimination or perpetual suppression of the tsetse populations (Vreysen et al. 2007).

This study presents the development of a sampling process that was designed for this particular area, combining modern tools such as remote sensing (RS) to map suitable habitats, geographic information systems, and the Global Positioning System (GPS) with mathematical modeling to maximize efficiency and accuracy of the sampling protocol in preparation for an AW-IPM tsetse campaign in the Niayes. The stratified sampling developed in this study could serve as a template for other tsetse control campaigns presently launched within the PATTEC initiative in West Africa.

\section{Materials and Methods}

The Study Area. The study area of $7,150 \mathrm{~km}^{2}$ is located along the Atlantic coast at $13.5-15.5^{\circ} \mathrm{N}$ and $16.5-17.5^{\circ} \mathrm{W}$. The area is $180 \mathrm{~km}$ long and $30-35 \mathrm{~km}$ wide and can be divided into three main sections: the Niayes in the North, the Sine Saloum in the South, and La Petite Côte in between (Fig. 1). Mean daily temperatures vary between $25^{\circ} \mathrm{C}$ and $30^{\circ} \mathrm{C}$ and relative humidity between 60 and $80 \%$. Annual precipitation is $200-500 \mathrm{~mm}$ with a rainy season from July to September.

Preliminary Surveys. A $5 \times 5$-km grid overlaying the entire target area ( 286 cells) was developed with letters and numbers allocated to rows and columns, respectively, to facilitate the field sampling procedures (Leak et al. 2008). During preliminary surveys between September and December 2007, a phytosociological census was carried out in 277 sites, of which 87 were selected as learning sites, to achieve the supervised classification (see below), and 190 as validating sites, to test the specificity and sensitivity of this classification (Fig. 2). All woody species were identified together with their stratum and cover class (five classes from 0 to $100 \%)$. Simultaneously, 50 unbaited Vavoua traps, constituted of a cone of mosquito netting placed over three panels of black and blue fabric with an angle of $120^{\circ}$ between them (Laveissière and Grébaut 1990), were deployed in the various habitats 


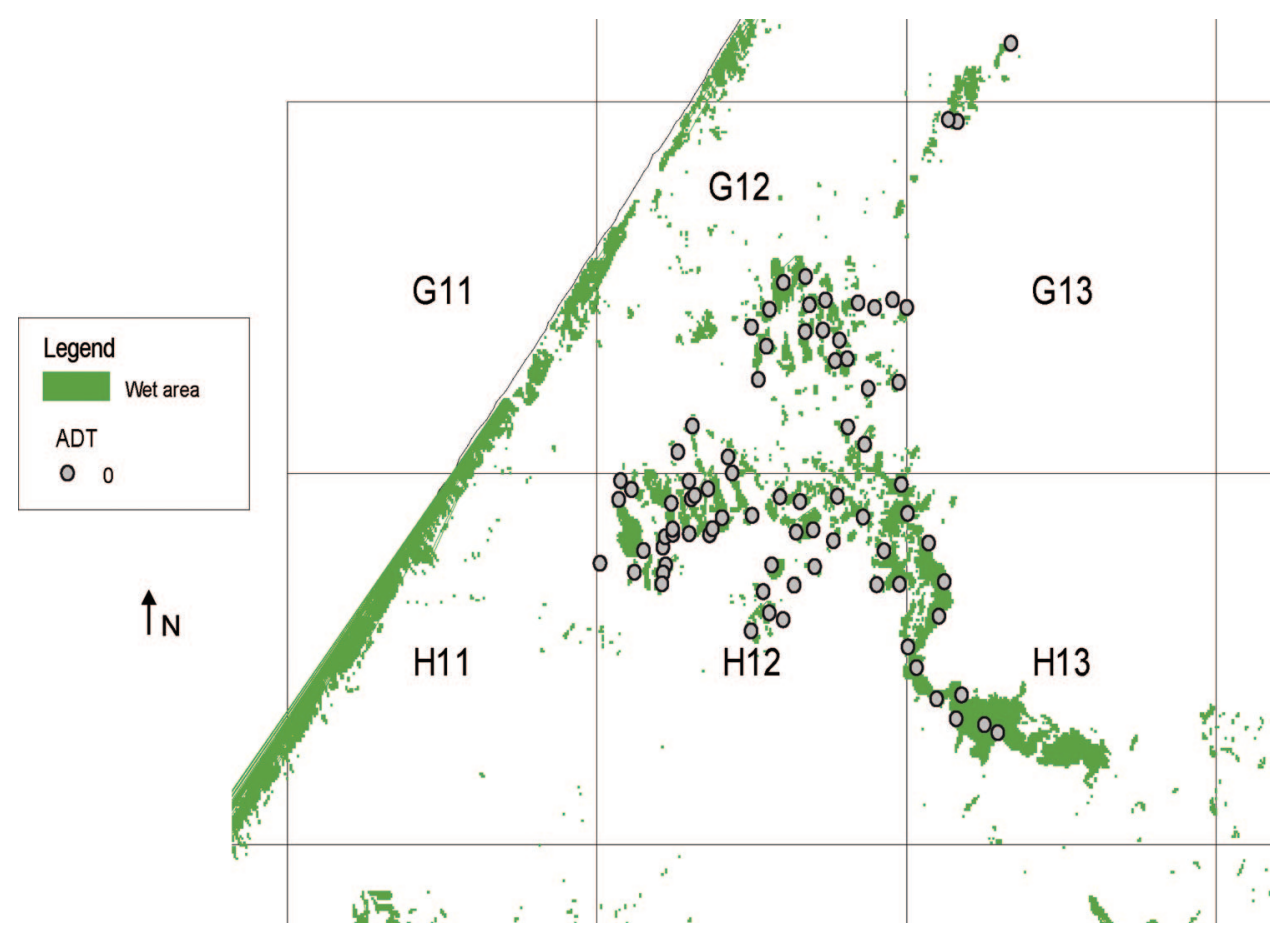

Fig. 2. Selection of trapping sites in the identified wet areas. The example of grid cells G11 to H13 is presented.

encountered to update our knowledge of tsetse habitat preferences. The phytosociological census was used to group the learning and validation sites in three classes of habitat suitability, based on the presence and abundance of forest plant indicators described previously (Bouyer et al. 2005), as follows: 1) not suitable when forest species or equivalent (tree crops) were absent; 2) suitable (S) when forest species (or cultivated trees) cover was above $50 \%$; and 3) suitable, but degraded (SD), when forest species were present, but with a cover of $<50 \%$.

Remote Sensing Analyses. A riverine tsetse species such as G. p. gambiensis cannot survive without suitable habitat containing forest tree species (or equivalent), so all vegetation with important photosynthetic activity was identified during a supervised classification from a LandSat $7 \mathrm{ETM}^{+}$image of April 2001, using the learning data set (see methodological details in Guerrini et al. 2008). The learning sites were used to define the regions of interest using the ENVI 4.3 software. These areas corresponded to the presence of ground water at the end of the dry season and are henceforth denoted wet areas. It was demonstrated before that photosynthetic activity at a smaller spatial scale is positively correlated with density and survival of G. p. gambiensis (Rogers and Randolph 1991). In view of the importance of obtaining an accurate picture of the distribution of G. p. gambiensis in the area, it was considered important to sample all $S$ and SD sites. The sensitivity of this classification was calculated as the number of S and SD validation sites located within the obtained wet areas divided by the total number of S and SD sites. The specificity was calculated as the ratio of S and SD sites within wet areas divided by the total number of sites within wet areas.

Entomological Sampling Strategy. Within each grid cell of the study area, one to 43 unbaited Vavoua traps (Vestergaard Frandsen ApS, Kolding, Denmark) were deployed in the available wet areas for tsetse fly sampling (Fig. 2). Males and females were counted separately, but their densities were merged in the present distribution analysis because they harbor similar habitat preferences. The field teams were equipped with GPS (Map 75 Garmin) handheld instruments that had the grid and polygons of the wet areas uploaded as polylines converted into track objects using the software DNR Garmin 5.2.25. Traps were deployed for $3 \mathrm{~d}$ and removed when at least one tsetse was captured during this period. When no tsetse was caught, traps remained deployed for up to $30 \mathrm{~d}$ and were checked every 1-5 d. In each trap site, ecological data were collected, including the vegetation type and tree cover.

Each grid cell was assigned to one of three possible categories, as follows: 1) no wet area in dry season: considered as tsetse-free, and no trapping was attempted; (2) no tsetse caught: if no tsetse flies were caught after sampling of the wet areas; (3) infested: if one tsetse fly was caught in at least one of the wet areas.

Probability Maps. Zero catch of tsetse flies does not mean absence of tsetse in the sampled area. Therefore, a recently published model (Barclay and Hargrove 2005) was used to evaluate the probability (or risk) that tsetse are actually present in a grid cell when not 
sampled through a given sampling effort (number of traps $\times$ days), i.e., for all the cells in the second category "no tsetse caught." In this model, the probability of observing a sequence of zero catches if in fact there are insects in the sampled area is given by the following: $P=\exp (-S t \sigma \lambda)$, where $S$ is the number of traps deployed in the total area, $t$ the number of days for which each trap is operated, $\sigma$ the trap efficiency, and $\lambda$ the population density (number of insects/area of suitable habitat). This probability was calculated for each grid cell using the specific number of traps, duration of trapping, and the total wet area surface in each grid cell. In the absence of any control effort, the minimum number of flies in the sample area was set at 10 , considering that this is an underestimation for any resident tsetse population in the absence of control effort. The goal of this exercise was to detect resident tsetse populations and was not related to assessing dispersal. This issue will be addressed later when mark-release-recapture experiments and population genetics (Bouyer et al. 2009) will be used to delineate the final target area. The trap efficiency, defined as the probability that a trap catches a fly in an area of $1 \mathrm{~km}^{2} / \mathrm{d}$, was defined as 0.01 . This figure was calculated from a reanalysis of raw capture data of $>400,000$ released flies during the elimination campaign against the same subspecies in Sidéradougou, Burkina Faso (data not shown) (Cuisance et al. 1984, Politzar and Cuisance 1984).

\section{Results}

Suitable Habitats. Eight types of habitat were identified as being suitable for G. p. gambiensis, which was confirmed by tsetse catches during the survey: 1) natural Guinean forest galleries close to permanent springs with riparian tree vegetation such as Nauclea latifolia, Phyllantus mullerianus, and Lonchocarpus sp. as predominant plant species; 2) semidisturbed Guinean riverine thickets with bushy vegetation replacing the original trees and where Alchornea cordifolia, Phyllantus mullerianus, and Phoenix reclinata predominate; 3) Euphorbia spp. fences located in flooded areas and generally mixed with the riverine thickets; 4) swampy forests, more or less natural, around permanent ponds and generally protected by a wall, as in city parks (Parc de Hann, Pasteur-Mbao); 5) riverine forests located inland adjacent to the mangroves, which do not flood during high tide and where the presence of fresh water springs allows the occurrence of non- or semihalophyte forest tree species such as Elais guineensis, $P$. reclinata, and A. cordifolia; 6) palm tree crops with $E$. guineensis as relics from gallery forests where people have kept only the useful plant species (often this habitat is reduced to food crops); 7) other tree crops (citrus fruit, mango), some of which are not well trimmed, and are watered the entire year or are in the vicinity of an underground hydrological network; and 8) lakes or swamps with reeds, which can be up to $3 \mathrm{~m}$ tall.

All of these habitats rely on the presence of fresh water during the dry season, which can be provided by underground river networks, springs, or human wa-
Table 1. Description of tsetse habitats in the Niayes area

\begin{tabular}{lcc}
\hline \multicolumn{1}{c}{ Habitats } & $\begin{array}{c}\text { \% trapping sites } \\
\text { within habitat }\end{array}$ & $\begin{array}{c}\text { \% infested sites } \\
\text { within this habitat }\end{array}$ \\
\hline Citrus tree plantations & $16(109)$ & $31(34)$ \\
Euphorbia hedges & $17(116)$ & $22(26)$ \\
Swampy forests & $7(48)$ & $16(8)$ \\
Mango tree plantations & $35(239)$ & $15(36)$ \\
Riverine thickets & $16(109)$ & $12(13)$ \\
Lake or swamp with reeds & $4(27)$ & $12(3)$ \\
Palm tree plantations & $15(102)$ & $6(6)$ \\
Food crops & $20(137)$ & $6(8)$ \\
Other tree plantations & $6(41)$ & $5(2)$ \\
Others & $8(55)$ & $2(1)$ \\
Forest galleries & $1(7)$ & $0(0)$ \\
\hline
\end{tabular}

The frequency distribution of the 683 trap locations in relation to the various preferred habitats encountered in the target area and percentage of sites infested by G. p. gambiensis are presented. The percentages in the first column are not cumulative to $100 \%$ because some of the trapping sites harbored mixed habitats. The habitats are classed from most to least infested. The number of trapping sites for each class is given in parentheses.

tering activities. In these sites, transpiring plants allow the maintenance of a certain level of humidity critical for the survival of riverine tsetse, and for this reason they cannot thrive in open savannah habitats (Challier 1973).

Mapping of Wet Areas. The sensitivity of the classification was 0.96 ( $1 \mathrm{~S}$ and $3 \mathrm{SD}$ not detected on 110 validation sites), whereas its specificity was only 0.43 , which means that $<50 \%$ of the wet areas actually harbored suitable habitats for tsetse.

From the 683 trap locations, only $61 \%$ were frequented by cattle, and insecticides for crop protection were applied in $48 \%$ of the sites. Permanent and temporary surface water was observed in 27 and $7 \%$ of the sites, respectively. The depth of ground water was shallower than $5 \mathrm{~m}$ in $58 \%$ of the sites, between 5 and $10 \mathrm{~m}$ in $12 \%$, and deeper than $10 \mathrm{~m}$ in the remaining sites.

Table 1 shows the distribution and rates of infestation in the various suitable habitats described above among the wet areas (some sites had a mixed habitat). The differences in infestation rates between habitats were significant (Pearson $\chi^{2}, \mathrm{df}=10, P<0.0001$ ). Much of the original vegetation (gallery forests, riverine thickets, palm tree forests) has disappeared, and, if present, was less infested with G. p. gambiensis than some artificial habitats like citrus tree plantations or Euphorbia hedges $(P<0.05)$, indicating that this species of tsetse is well adapted to artificial habitats in the Niayes, given suitable humidity.

Entomological Results. Of the 286 grid cells in the study area, wet areas were absent in 87 cells, and 105 of the remaining 199 cells were surveyed. Traps were set from December 2007 to March 2009 in 683 sites, corresponding to 3,564 trapping events. G. p. gambiensis was the only tsetse species sampled, and flies were captured in $27 \%$ of the trapping sites distributed over 23 grid cells, of which 21 were located in the Niayes area and two in the Sine Saloum. Although the mean apparent density of G. p. gambiensis was $0.41 \mathrm{flies} / \mathrm{trap} / \mathrm{d}$ (SD 1.70), fly catches fluctuated between 0 and 18 flies/trap/d, indicating a very heterogeneous fly distribution (Fig. 3). The 


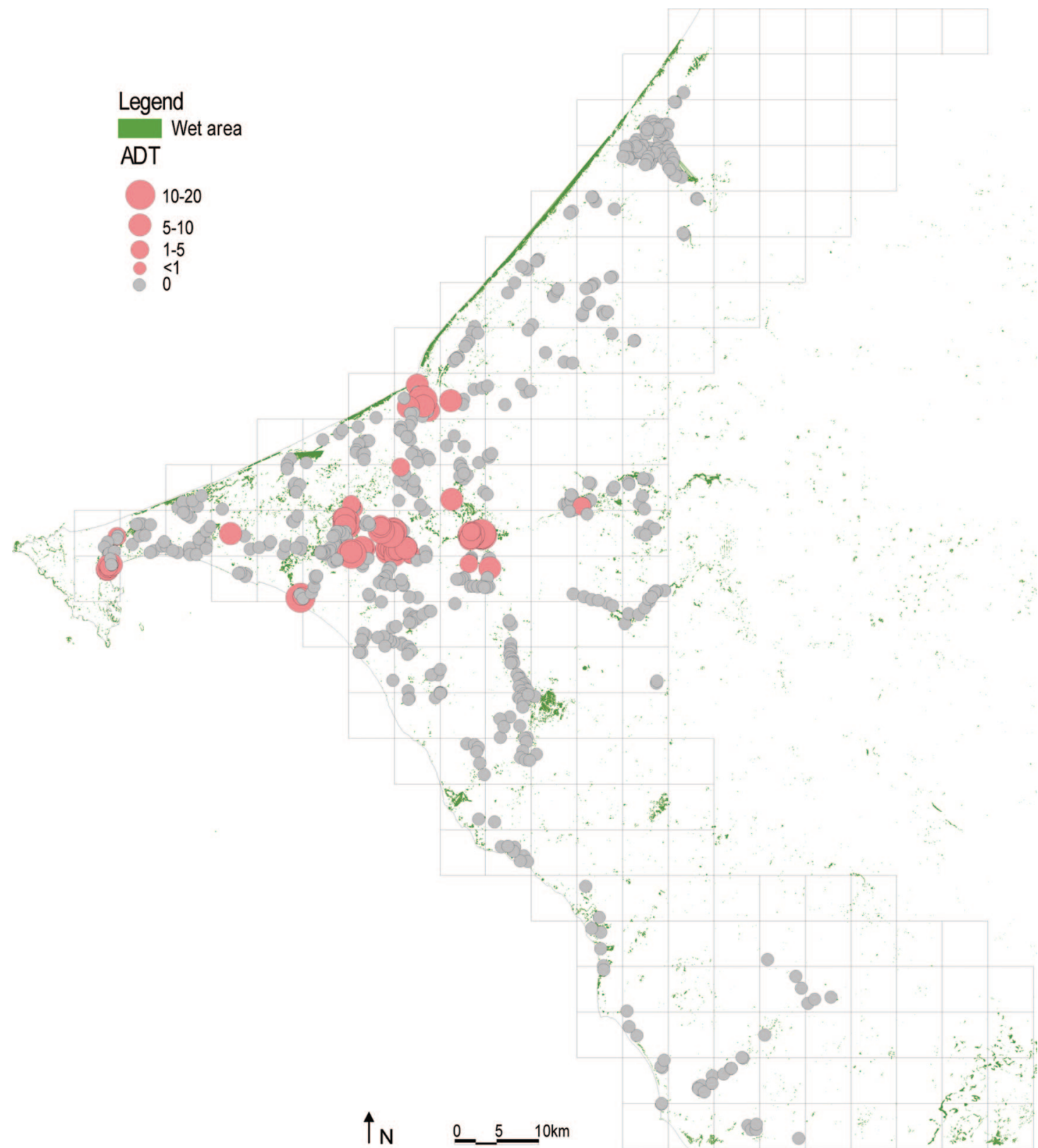

Fig. 3. The apparent densities of G. p. gambiensis in the Niayes area of Senegal. Trap catches (number of flies/trap/d) are given for the dry season of 2008 .

total observed infested area was $575 \mathrm{~km}^{2}$, of which 525 $\mathrm{km}^{2}$ was situated in the Niayes area. The trapping results seemed to indicate that the infested area was surrounded in the north, east, and south by grid cells where no tsetse flies were caught.

Probability Maps. Of the 105 grid cells where traps were deployed, the trap surveys had already demonstrated the presence of flies in 21 cells. The probability model described above was applied to the remaining 84 grid cells where no flies were trapped. The analysis indicated a probability of tsetse presence below 0.05 (the level of risk accepted) in 68 grid cells and above 0.05 in the remaining 16 grid cells. Fig. 4 presents graphically the probability of tsetse presence in those cells around the confirmed tsetse-infested area.

\section{Discussion}

The collection of entomological baseline data from an area that is the target of an AW-IPM program is a prerequisite for the development of an appropriate control strategy (Vreysen 2005, Leak et al. 2008). Data 


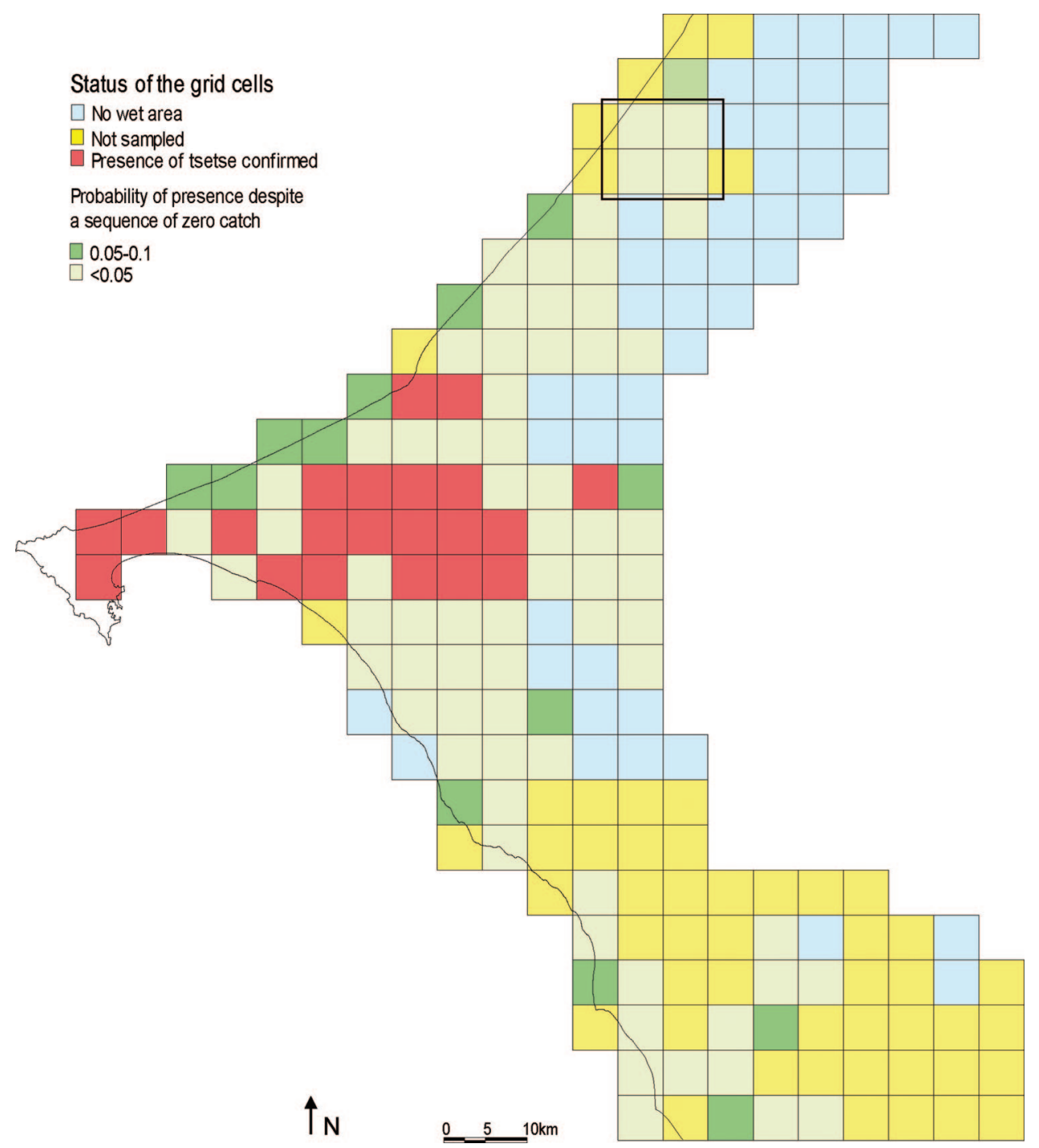

Fig. 4. Probability of presence of G. p. gambiensis. This probability was implemented in the grid cells where no flies were trapped and which are situated around the confirmed infested area. The black rectangle at the top represents the cells G11 to H13 shown in Fig. 2.

on tsetse species present, and the relative abundance, distribution, and temporal and spatial dynamics of the population will enable program managers to select appropriate control tactics and develop a plan of how and where to deploy these as adapted to the characteristics of the target zone/population. The baseline data will also allow accurate monitoring of the control operation and to continuously assess progress made (Vreysen 2005). For large targeted areas (e.g., the tsetse project in Ethiopia) (Alemu et al. 2007), logistics, time, and economics will limit the amount of trapping that can be carried out. Therefore, a representative grid-based sampling approach (Leak et al. 2008) has been proposed that aims to collect data from carefully selected habitats within a given grid cell that are considered to be representative for other similar habitat areas in that grid cell. The sampling process described in this work is based upon this approach, but was fine-tuned and improved using modern tools of spatial analysis (geographic information systems/RS/ GPS) (Cox and Vreysen 2005), mathematical modeling, and accounting for the ecological affinities of a riverine tsetse species such as G. p. gambiensis (Challier 1973). Although the operational phase of the elimination campaign has not been initiated yet in Senegal, and most other countries under the PATTEC initiative are in the phase of data collection, we believe that the methodology described in this study would assist in making the data collection more cost effective.

The Niayes of Senegal receives $<500 \mathrm{~mm}$ of rain annually, and human development has significantly modified the habitats suitable for G. p. gambiensis, which illustrates the tremendous adaptability of the 
species. A G. p. gambiensis population is even found in the Parc de Hann located in the densely populated city center of Dakar. The park is a $0.4-\mathrm{km}^{2}$ forest swamp protected by a stone wall, and contains a zoo with caged animals, a pony club, and a high number of daily visitors, i.e., all the requirements for the species to proliferate.

In the Niayes, high rates of tsetse infestation were encountered in perennial crop areas, especially citrus and in Euphorbia hedges, swamps with reeds, and riparian thickets. Tsetse presence was highly correlated with wet areas, where particular conditions allow fresh water to be available during the dry season. Mangrove and inland riverine forests adjacent to mangroves were absent in the Niayes area, but were present in the southern part of the study area, i.e., the Sine Saloum (Fig. 1). The inland riverine forests adjacent to mangroves should not be confounded with the mangroves themselves, where Rizophora spp. and Avicenia spp. are the predominant species. Mangrove vegetation is not suitable for $G$. p. gambiensis breeding (i.e., larviposition) because it is flooded every day (Touré 1971, 1974), but this habitat is often frequented by flies seeking hosts for a blood meal, resulting in high population densities. In Senegal, G. $p$. gambiensis is absent from the northern part of the Sine Saloum, where a decrease in annual rainfall has led to a disappearance of the inland riverine forests adjacent to mangroves. In addition, the area has experienced a reduction of the Rizophora because of an increase in salinity, resulting in a habitat that cannot offer enough shelter to tsetse anymore. Even in the infested area of the southern part of the Sine Saloum, the distribution of G. p. gambiensis is very patchy, and mostly confined to islands or riverbanks covered with inland riverine forests adjacent to mangroves.

The remote sensing analysis allowed us to restrict the sampling area to only $4 \%$ of the original target area. It showed a very high sensitivity, but a low specificity, which is reflected in the sampling results, i.e., tsetse flies were trapped in $<30 \%$ of the sampling sites. High sensitivity and low specificity increase the probability that most of the sites inhabited by tsetse are detected, which is crucial in an AW-IPM campaign, even if it will require a more intense sampling effort. In the four sites (one $\mathrm{S}$ and three SD) not detected by the classification, no flies were trapped even after deployment of the traps for 1 mo. Moreover, the wet area classification permitted the detection of tsetse flies in unexpected sites such as a military camp, where sampling would never have been implemented without this wet area classification. The remoteness of some of the wet areas (e.g., suitable trapping sites were sometimes located at a distance of $2 \mathrm{~km}$ from a track) and the small size of the suitable vegetation patches necessitated the use of GPS guidance to locate these sites in the grids. The entire sampling process was therefore driven by the remote sensing analyses and could be implemented by incorporating the RS data in the GPS. It is still probable that not all potential habitats have been detected in view of the low resolution $(30 \mathrm{~m})$ of the LandSat image, and the pixels corresponding to suitable habitat could be easily diluted in surrounding pixels that might be unsuitable (de La Rocque et al. 2005, Bouyer et al. 2006).

The calculated probability of presence using the Barclay and Hargrove model (Barclay and Hargrove 2005) provides a method to improve the cost effectiveness of the sampling process. Despite the zero catches in some of the grid cells, the model likely overestimated the probability of presence as: 1$)<50 \%$ of the wet areas are actually suitable for G. p. gambiensis, and 2) the density of the source tsetse populations is probably higher than the assumed 10 in $25 \mathrm{~km}^{2}$ in the absence of control efforts. In Burkina Faso, densities of $>3,500$ flies were observed in riparian forest along a $10-\mathrm{km}$ river section (Bouyer et al. $2007 \mathrm{~b}$ ), and in some localities of Senegal (e.g., Pout), $>500$ flies were captured in $3 \mathrm{~d}$ with 10 Vavoua traps during the present sampling campaign. The application of the model proved to be a convenient tool to prioritize additional sampling efforts in grid cells where the sampling was considered insufficient. The quantitative methods, such as the remote sensing analysis that permitted the classification of the ecological important areas (i.e., wet areas) for G. p. gambiensis and the Barclay and Hargrove model enabled the optimization of the entomological sampling process before initiation of the operational phase of the actual control campaign in Senegal, which started in mid2009. Taking into consideration the ecological characteristics of other vectors or insect pests, the described approach could easily be expanded to improve sampling procedures in preparation of AW-IPM campaigns.

Although not all grid cells were sampled in the current study, the survey methodology was adapted and adjusted as a result of this analysis during the whole sampling process, and hence, the sampling was directed toward those cells where the level of confidence was the lowest (i.e., where the former probability of presence was the highest). Some of the grid cells where no tsetse were captured during the surveys still have a high probability of being infested with tsetse; they will so be considered infested and treated as well, when in contact with infested cells. Additional sampling in these cells will be carried out during the control campaign. This information will thus be taken into consideration when the total target control area will be determined.

Despite the assumed high accuracy of the described sampling process, it will be impossible to identify all the sites where tsetse are present at a given time for the following reasons: 1 ) some wet areas might remain undetected in the classification process; 2 ) the probability of fly presence will remain high in some areas, even with zero catches because of the necessity of a trade-off between accuracy and cost; and 3) the entire sampling process is based upon dry season conditions, but it is known that G. p. gambiensis tsetse are able to move through and breed in other habitats during the wet season (Cuisance et al. 1985, Bouyer et al. 2007a), even if restricted again during the following dry season. Their distribution, therefore, must be seen as 
dynamic and will be influenced by climatic factors such as rainfall, which can vary from year to year.

The first elimination effort in the 1970s most likely failed (Touré 1973), because not all ecologically important areas were identified and treated; e.g., the $G$. p. gambiensis population in Pout, which was observed to have a high population density, was unknown and, hence, not targeted at the time (S. Touré, personal communication). A population genetics study recently confirmed the isolation of the tsetse populations of the Niayes from those of the Sine Saloum, i.e., the nearest population of the main tsetse belt in southern Senegal (Solano et al. 2010). The use of old specimens from the Niayes, kept in ISRA collections, will also assist with testing this hypothesis.

The persistence of small pockets is particularly problematic when stationary control techniques such as traps or screens impregnated with insecticides are used in a fragmented landscape such as the Niayes and La Petite Côte. In such ecosystems, tsetse dispersal is likely to be low, and the tsetse populations likely to be highly structured (Bouyer et al. 2007b, 2009), which corresponds to a metapopulation rather than to an homogeneous panmictic population (Hanski and Gaggiotti 2004).

The results that will be derived from a complete analysis of the collected data sets (entomological, parasitological, serological, etc.) will allow the project managers to select and combine control tactics that are best suited to create a sustainable zone free of $G$. p. gambiensis in the Niayes.

\section{Acknowledgments}

We are very thankful to the veterinary staff involved in the field studies, particularly Abdou Gaye Mbaye, Babacar Camara, Babel Sow, Aïda Gaye, Mamadou Demba, Alphonse Manga, and Mansour Fall. We are indebted to the Direction des Services Vétérinaires and ISRA-LNERV for providing excellent working conditions.

\section{References Cited}

Alemu, T., B. Kapitano, S. Mekonnen, G. Aboset, M. Kiflom, B. Bancha, G. Woldeyes, K. Bekele, and U. Feldmann. 2007. Area-wide control of tsetse and trypanosomosis: Ethiopian experience in the Southern Rift Valley, pp. 325-335. In M. Vreysen, A. S. Robinson, and J. Hendrichs (eds.), Area-wide control of insect pests: from research to field implementation. Springer, Dordrecht, The Netherlands.

Barclay, H. J., and J. W. Hargrove. 2005. Probability models to facilitate a declaration of pest-free status, with special reference to tsetse (Diptera: Glossinidae). Bull. Entomol. Res. 95: 1-11.

Bouyer, J., L. Guerrini, J. César, S. de la Rocque, and D. Cuisance. 2005. A phyto-sociological analysis of the distribution of riverine tsetse flies in Burkina Faso. Med. Vet. Entomol. 19: 372-378.

Bouyer, J., L. Guerrini, M. Desquesnes, S. de la Rocque, and D. Cuisance. 2006. Mapping African animal trypanosomosis risk from the sky. Vet. Res. 37: 633-645.

Bouyer, J., A. Sibert, M. Desquesnes, D. Cuisance, and S. de La Rocque. 2007a. A model of diffusion of Glossina pal- palis gambiensis (Diptera: Glossinidae) in Burkina Faso, pp. 221-228. In M.J.B. Vreysen, A. S. Robinson, and J. Hendrichs (eds.), Area-wide control of insect pests: from research to field implementation. Springer, Dordrecht, The Netherlands.

Bouyer, J., S. Ravel, L. Vial, S. Thévenon, J.-P. Dujardin, T. de Meeus, L. Guerrini, I. Sidibé, and P. Solano. 2007b. Population structuring of Glossina palpalis gambiensis (Diptera: Glossinidae) according to landscape fragmentation in the Mouhoun river, Burkina Faso. J. Med. Entomol. 44: 788-795.

Bouyer, J., T. Balenghien, S. Ravel, L. Vial, I. Sidibé, S. Thévenon, P. Solano, and T. De Meeûs. 2009. Population sizes and dispersal pattern of tsetse flies: rolling on the river? Mol. Ecol. 18: 2787-2797.

Brunhes, J., D. Cuisance, B. Geoffroy, and J.-P. Hervy. 1998. Les glossines ou mouches tsé-tsé. CIRAD/ORSTOM, Montpellier, France.

Camara, M., D. Kaba, M. Kagbadouno, J. R. Sanon, P. Ouendeno, and P. Solano. 2005. La Trypanosomose Humaine Africaine en zone de mangrove en Guinée: caractéristiques épidémiologiques et cliniques de deux foyers voisins. Med. Trop. 65: 155-161.

Challier, A. 1973. Ecologie de Glossina palpalis gambiensis Vanderplank, 1949 (Diptera-Muscidae) en savane d'Afrique occidentale. ORSTOM, Paris, France.

Cox, J.S.H., and M.J.B. Vreysen. 2005. Use of geographic information systems and spatial analysis in area-wide integrated pest management programmes that integrate the sterile insect technique, pp. 453-477. In V. A. Dyck, J. Hendrichs, and A. S. Robinson (eds.), Sterile insect technique: principles and practice in area-wide integrated pest management. Springer, Dordrecht, The Netherlands.

Cuisance, D., H. Politzar, P. Merot, and I. Tamboura. 1984. Les lâchers de mâles irradiés dans la campagne de lutte intégrée contre les glossines dans la zone pastorale de Sidéradougou, Burkina Faso. Rev. Elev. Méd. Vét. Pays Trop. 37: 449-468.

Cuisance, D., J. Février, J. Dejardin, and J. Filledier. 1985. Dispersion linéaire de Glossina palpalis gambiensis et G. tachinoides dans une galerie forestière en zone soudanoguinéenne (Burkina Faso). Rev. Elev. Méd. Vét. Pays Trop. 38: 153-172.

de La Rocque, S., J. F. Michel, J. Bouyer, G. De Wispelaere, and D. Cuisance. 2005. Geographical Information Systems in parasitology: a review of potential applications using the example of animal trypanosomosis in West Africa. Parassitologia 47: 97-104.

Dyck, V. A., G. Hendrickx, and A. S. Robinson. 2005. Sterile insect technique. Springer, International Atomic Energy Agency, Vienna, Austria.

Feldmann, U., V. A. Dyck, R. C. Mattioli, and J. J. Jannin. 2005. Potential impact of tsetse fly control involving the sterile insect technique, pp. 701-723. In V. A. Dyck, J. Hendrichs, and A. S. Robinson (eds.), Sterile insect technique: principles and practice in area-wide integrated pest management. Springer, Dordrecht, The Netherlands.

Guerrini, L., and J. Bouyer. 2007. Mapping African animal trypanosomosis risk: the landscape approach. Vet. Ital. 43: 643-654.

Guerrini, L., J. P. Bord, E. Ducheyne, and J. Bouyer. 2008. Fragmentation analysis for prediction of suitable habitat for vectors: the example of riverine tsetse flies in Burkina faso. J. Med. Entomol. 45: 1180-1186. 
Hanski, I., and O. E. Gaggiotti. 2004. Ecology, genetics and evolution of metapopulations. Elsevier Academic, Amsterdam, The Netherlands.

Itard, J., D. Cuisance, and G. Tacher. 2003. Trypanosomoses: historique: répartition géographique, pp. 1607-1615. In P.-C. Lefèvre, J. Blancou, and R. Chermette (eds.), Principales maladies infectieuses et parasitaires du bétail: Europe et Régions chaudes. Lavoisier, Paris, France.

Klassen, W. 2005. Area-wide integrated pest management and the sterile insect technique, pp. 39-68. In V. A. Dyck, J. Hendrichs, and A. S. Robinson (eds.), Sterile insect technique: principles and practice in area-wide integrated pest management. Springer, Dordrecht, The Netherlands.

Laveissière, C., and P. Grébaut. 1990. Recherches sur les pièges à glossines (Diptera, Glossinidae): mise au point d'un modèle économique: le piège "Vavoua." Trop. Med. Parasitol. 41: 185-192.

Leak, S.G.A., D. Ejigu, and M.J.B. Vreysen. 2008. Collection of entomological baseline data for tsetse area-wide integrated pest management programmes: FAO animal production and health guidelines. Food and Agriculture Organization of the United Nations, Rome, Italy.

Morel, P. C., and S. Touré. 1967. Glossina palpalis gambiensis Vanderplank 1949 (Diptera) dans la région des Niayes et sur la Petite Côte (République du Sénégal). Rev. Elev. Méd. Vét. Pays Trop. 20: 571-578.

Pinchbeck, G. L., L. J. Morrison, A. Tait, J. Langford, L. Meehan, S. Jallow, J. Jallow, A. Jallow, and R. M. Christley. 2008. Trypanosomosis in Gambia: prevalence in working horses and donkeys detected by whole genome amplification and PCR, and evidence for interactions between trypanosome species. BMC Vet. Res. 4: 7.

Politzar, H., and D. Cuisance. 1984. An integrated campaign against riverine tsetse flies Glossina palpalis gambiensis and Glossina tachinoides by trapping and the release of sterile males. Insect Sci. Appl. 5: 439-442.
Rogers, D. J., and S. E. Randolph. 1991. Mortality rate and population density of tsetse flies correlated with satellite imagery. Nature 351: 739-741.

Seck, M. T., J. Bouyer, B. Sall, Z. Bengaly, and M.J.B. Vreysen. 2010. The Prevalence of African animal trypanosomoses and tsetse presence in Western Senegal. Parasite (in press).

Solano, P., D. Kaba, S. Ravel, N. Dyer, B. Sall, M.J.B. Vreysen, M. T. Seck, H. Darbyshir, L. Gardes, M. J. Donnelly, T. de Meeûs, and J. Bouyer. 2010. Tsetse population genetics as a tool to choose between suppression and elimination: the case of the Niayes area in Senegal. Plos Tropical Neglected Diseases 4: e692.

Touré, S. 1971. Les glossines (Diptera, glossinidae) du Sénégal: ecologie, répartition géographique et incidence sur les trypanosomoses. Rev. Elev. Méd. Vét. Pays Trop. 24: 551-563.

Touré, S. 1973. Lutte contre Glossina palpalis gambiensis dans la région des niayes du Sénégal. Rev. Elev. Méd. Vét. Pays Trop. 26: 339-347.

Touré, S. 1974. Note sur quelques particularités dans l'habitat de Glossina palpalis gambiensis Vanderplank, 1949 (Diptera, Glossinidae) observées au Sénégal. Rev. Elev. Méd. Vét. Pays Trop. 27: 81-94.

Vreysen, M.J.B. 2005. Monitoring sterile and wild insects in area-wide integrated pest management programmes, pp. 325-361. In V. A. Dyck, J. Hendrichs, and A. S. Robinson (eds.), Sterile insect technique: principles and practice in area-wide integrated pest management. Springer, Dordrecht, The Netherlands.

Vreysen, M., A. S. Robinson, and J. Hendrichs. 2007. Areawide control of insect pests, from research to field implementation. Springer, Dordrecht, The Netherlands.

Received 10 June 2009; accepted 24 March 2010. 